\title{
Adult Pre-Service Teachers Applying 21st Century Skills in the Practice
}

\author{
By Päivi Valli* \\ Päivi Perkkilä ${ }^{\dagger}$ \\ Raine Vallit
}

In this research we present how a group of Finnish adult preservice teachers $(n=21)$ incorporated $21^{\text {st }}$ CS through their methods of working instructional methods in the final practicum in autumn 2013. The research material consists of pre-service teacher's practicum plans, taped lessons and written practicum synthesis. The nature of teaching has changed significantly during the past decades, as a result of which teaching has never been more difficult or more important. This is a challenge also for teacher education programs. The adult teacher education program at Kokkola University Consortium Chydenius focuses on developing $21^{\text {st }}$ century skills $\left(21^{\text {st }} \mathrm{CS}\right)$ to enhance the use of technology, to support critical thinking and problem solving, and to enable collaboration and creativity during studies. Our curriculum is designed to produce deep understanding and authentic application of $21^{\text {st }}$ CS in all practicums. Because Finnish teachers are free to choose their methods, it is important that pre-service teachers are aware of $21^{\text {st }} \mathrm{CS}$. The current Finnish national curriculum includes some $21^{\text {st }} \mathrm{CS}$, such as learning through peer interaction, helping students (= pre-service teachers) take responsibility for their learning, and helping them develop strategies for applying skills in novel situations. At the moment, Finland is in the midst of a curriculum reform that includes consideration of adopting $21^{\text {st }}$ CS more clearly in learning situations. We found that $21^{\text {st }} C S$ were taken into account in planning learning environments, but how to apply $21^{\text {st }}$ CS in classroom demanded deeper understanding and abilities of applying these skills in practice.

\footnotetext{
*University Teacher, Kokkola University Consortium Chydenius, University of Jyväskylä, Finland.

†Senior Lecturer, Kokkola University Consortium Chydenius, University of Jyväskylä, Finland.

"Professor, Kokkola University Consortium Chydenius, University of Jyväskylä, Finland.
} 


\section{Introduction}

The high-quality education of Finland is based on high-quality teacher training. Since teaching is a respected profession universities can select the most suitable and motivated students (from all applicants). At all levels teachers are required to have a Master's Degree and universities are allowed to decide on their curriculum independently within a certain framework. The goal is to train research-oriented teachers who have the ability to solve problems independently. Teacher training also includes pedagogical studies (60 ECTS ${ }^{1}$ ) and guided teaching practice. Teacher training must constantly evolve to face the challenges in society, such as technological development and changing working life skills. In Finland, teachers have the freedom and possibility to work in the way they choose, which is based on confidence in teachers. The purpose of teacher training is to provide graduating teachers with versatile and necessary knowledge and skills. (Niemi \&Jakku-Sihvonen, 2011; Sahlberg, 2007)

Teacher graduates face rapidly changing society through their work at school and the school must respond to the demands of changing society. According to Välijärvi (2005), future teachers are expected to have more and more knowledge and skills to face and understand the challenges of changing society. They must respond to these changes and develop the school system. Thus, one of the tasks of teacher education is to train teachers who have the skills and knowledge that future citizens will need. To refer these future citizens' skills and knowledge, international research and education planners have developed the concept $21^{\text {st }}$ century skills/learning (Partnership for $21^{\text {st }}$ century skills, 2011; Häkkinen, Juntunen\&Laakkonen, 2012; Lankinen, 2010). Future skills and knowledge include, among others, critical thinking and problem solving, collaboration, creativity, and the use of information technology in education and in learning environments (Kuuskorpi, 2012; Ananiadou \& Claro, 2009). In Finland, teachers' professional competence is of high quality, and employers' confidence in their abilities is strong. Each teacher defines how they incorporate $21^{\text {st }} \mathrm{CS}$ in their classroom. Many teachers also focus on social and cooperative skills. However, some studies show that teachers prefer traditional teaching and learning situations (for example teacher centered teaching methods) over $21^{\text {st }} \mathrm{CS}$, and they consider $21^{\text {st }} \mathrm{CS}$ as the most demanding part of the curriculum. (Adamson \& Darling-Hammond, 2010). A study conducted by Norrena, Kankaanranta and Nieminen (2011) showed that many of the schools participating their research lack understanding of what $21^{\text {st }}$ century skills are and how they can be applied to learning situations. Thus, teachers need better possibilities for professional development to be able to apply $21^{\text {st }}$ century skills in learning situations. The aim of this research is to examine the manifestation of the above mentioned skills (critical thinking and problem solving, collaboration, creativity, and the use of information technology) in the learning whole plans that teacher students $(n=21)$ created and in their work during the classroom practice period. From the point of view of teacher education it is important to get more information of how our 
students have learnt to use $21^{\text {st }} \mathrm{CS}$ in practice. So far, however, there has been little discussion about $21^{\text {st }} \mathrm{CS}$ in teacher education. What is not yet clear is the impact of studies during teacher education on teacher students' skills to apply $21^{\text {st }} \mathrm{CS}$ in the practice.

\section{Examining Future Skills}

Future teachers are required to understand what knowledge means in the future as regards teaching and learning. Teachers must have a sufficient understanding of enhancing and applying $21^{\text {st }}$ century skills. As the educator of future teachers, teacher training has a remarkable role in ensuring that teachers have sufficiently information and skills so that they master these skills. This requires a determined and investigative approach so that putting these skills into practice can be supported and examined during education.

In the introduction we referred to international research and education planning as regards the implementation of the concept future skills (for example Partnership for $21^{\text {st }}$ century skills, 2011). The concepts future skills, $21^{\text {st }}$ century skills, and citizen skills are used as equal in this article. The basis for all three concepts is $21^{\text {st }} \mathrm{CS}$ which have been defined in different ways and from different points of view. The definitions of the international research project Assessment and Teaching for $21^{\text {st }}$ Century Skills (ATC21S) are based on vast international co-operation that also Finland took part in. In Europe, $21^{\text {st }}$ century skills have mainly been defined according to The European Reference Framework of Key Competences 2009 report (Gordon et al., 2009), which is based on the European Union Lifelong Learning program. In addition, the definitions of $21^{\text {st }} \mathrm{CS}$ used in this study are based on definitions used in a program of The International Society for Technology (NETS) called Partnership for $21^{\text {st }}$ Century Skills that defines $21^{\text {st }}$ century skills (P21Skills 2011).

Our study focuses on four central $21^{\text {st }} \mathrm{CS}$, which are critical thinking and problem solving, collaboration, creativity, and the use of information technology (see Table 1). These skills are central skills of thinking, working, and mastery of tools, and they are considered central also in the class teacher adult education curriculum of Kokkola University Consortium Chydenius.

Collaboration means communal activity between pupils that is based on the reliance that everyone makes an effort to achieve shared goals. It is essential that ideas and thoughts are elaborated together, and the goal is that pupils can excel themselves when getting ideas, help and support from each other and the teacher. (Hakkarainen, Bollström-Huttunen, Pyysalo \& Lonka, 2005) Critical thinking and problem solving mean for example effective analyzing and the ability to assess claims and beliefs, as well as to solve different unfamiliar problems in innovative ways. (Adamson \& DarlingHammond, 2010) In this study, creativity is seen as the ability to produce novel solutions to familiar problem situations, or to use old means in new ways. In 
classroom situations creativity reflects in pupils' possibilities to use imagination and be inventive and encouraged to express their own ideas, as well as to build understanding of things without rush. These skills will be required of future employees, and therefore school must invest in them. Education enables a pupil to fully participate in the operation of modern society. Also the pupil's activity, creativity, resourcefulness, persistence and cooperativeness can be developed through these skills. The school world has talked about the importance of problem solving skills for decades, but their use in school needs to be put effort on. The results of latest Pisa study show that Finland succeeded well in problem solving skills. One reason for this success was persistence in problem solving. It was the strongest among analogue countries and twice as great as the average in OECD countries. Thus, encouraging persistence successfully has an especially great role in making problem solving skills better in Finland. Another reason was pupils' openminded attitude towards problem solving tasks, which was shown in Finland's results more strongly than in any other country. (Ministry of Education and Culture, 2014.) Methods that are based on problem solving skills can be used to support also creative group processes that require cooperative skills and creative thinking and attitude of group members.

In addition to absorbing knowledge, more attention is now being paid on acquiring skills as well. Acquiring skills demands learning situations that allow collaboration, working on authentic problems, and commitment to community. This requires untraditional strategies and pupil-centered methods as well as teachers' genuine interest in making teaching and learning better. The mastery of future skills should be seen as a broader concept than the concept skill in general. Mastering future skills requires one to have deeper, procedural knowledge that synthesizes information and skills (Ryle 1949). Dewey (1929), already, had the idea about skills or know-how. There are two levels in acquiring skills: on the first level one is able to use the skills and on the second level one can apply skills according to situations. Thus, experience of $21^{\text {st }}$ century skills is not the same as to practice them. Experience has to do with using skills in learning situations, but practice includes an effort to develop these skills by, for example, reflecting on what went wrong or making strategies to be able do better. Practice also demands feedback. (Rotherham \& Willingham, 2010.) According to Ananiadou and Claro (2009), $21^{\text {st }}$ century competence can be divided into competence and skills. This means that skill is understood as an ability to perform a task or solve problems. Competence, on the other hand, is the ability to apply learning outcomes appropriately in different situations. Thus, competence is a broader concept that may comprise different skills, but also knowledge or attitudes. 
Table 1. $21^{\text {st }}$ Century Skills (Partnership for $21^{\text {st }}$ Century Skills 2011)

\begin{tabular}{|c|c|c|}
\hline \multicolumn{3}{|c|}{$21^{\text {st }}$ Century Learning Skills } \\
\hline $\begin{array}{c}\text { Information and } \\
\text { Communication Skills }\end{array}$ & $\begin{array}{l}\text { Thinking and } \\
\text { Problem Solving } \\
\text { Skills }\end{array}$ & $\begin{array}{l}\text { Interpersonal and Self- } \\
\text { Directional Skills }\end{array}$ \\
\hline $\begin{array}{l}\text { Information and Media } \\
\text { Literacy Skills } \\
\text { - Accessing and } \\
\text { managing information. } \\
\text { - Integrating and } \\
\text { creating information. } \\
\text { - Evaluating and } \\
\text { analyzing information. } \\
\text { Communication Skills } \\
\text { Understanding, } \\
\text { managing, and creating } \\
\text { effective communication } \\
\text { - orally, } \\
\text { - in writing, } \\
\text { - using multimedia. }\end{array}$ & $\begin{array}{l}\text { Critical Thinking } \\
\text { and Systems } \\
\text { Thinking } \\
\text { - Exercising sound } \\
\text { reasoning. } \\
\text { - Making complex } \\
\text { choices. } \\
\text { - Understanding the } \\
\text { interconnections } \\
\text { among systems. } \\
\text { Problem } \\
\text { Identification, } \\
\text { Formulation } \\
\text { Solution } \\
\text { Ability to } \\
\text { - frame, } \\
\text { - analyze, } \\
\text { - solve problems. } \\
\text { Creativity and } \\
\text { Intellectual } \\
\text { Curiosity } \\
\text { - To develop, } \\
\text { - implement, } \\
\text { - communicate } \\
\text { - new ideas to } \\
\text { others. }\end{array}$ & $\begin{array}{l}\text { Interpersonal and } \\
\text { Collaborative Skills } \\
\text { - Demonstrating } \\
\text { teamwork and working } \\
\text { productively with others. } \\
\text { - Demonstrating the } \\
\text { ability to adapt to } \\
\text { varied roles and } \\
\text { responsibilities. } \\
\text { - Exercising empathy and } \\
\text { respecting diverse } \\
\text { perspectives. } \\
\text { Self-Direction } \\
\text { - Monitoring one's own } \\
\text { understanding and } \\
\text { learning needs. } \\
\text { - Locating resources. } \\
\text { - Transferring learning } \\
\text { from one domain to } \\
\text { another. } \\
\text { Accountability and } \\
\text { Adaptability and personal } \\
\text { - Exercising and } \\
\text { responsibility } \\
\text { flexibility in personal, } \\
\text { workplace and and } \\
\text { community contexts. } \\
\text { - Setting and meeting } \\
\text { high standards and } \\
\text { goals for oneself and } \\
\text { others. } \\
\text { Social Responsibility } \\
\text { - Acting responsibly with } \\
\text { the interests of the larger } \\
\text { community in mind. } \\
\text { - Demonstrating ethical } \\
\text { behavior in personal, } \\
\text { workplace and contexts. } \\
\text { community }\end{array}$ \\
\hline
\end{tabular}


In Finland, the focus has been especially on improving pupils' metacognitive and learning to learn skills. The national core curriculum for basic education is a document that describes the most important skills and essential concepts on an annual basis. The curriculum guides teachers in communal development of a local curriculum and evaluation. The aim is to encourage pupils to take an active role in their learning: to find, analyze and use information in problem solving. The current curriculum includes some $21^{\text {st }}$ CS, such as peer learning, pupils' responsibility of their learning and using and applying strategies in novel contexts. At the moment, the national core curriculum is being reformed, and the new curriculum will comprise $21^{\text {st }} \mathrm{CS}$ better, also at legislative level. According to Adamson and Darling-Hammond (2010) the curriculum frameworks provide direction for teacher training, professional development, and classroom practice.

\section{The Final Practice Period in Adult Class Teacher Education}

In Finland universities are autonomous in planning teacher education curricula and their implementation in teaching practice. National legislation only gives major guidelines for teacher education and does not regulate how many hours pre-service teachers engage in practice. Commonly in the beginning, practical studies guide pre-service teachers to observe school life and the pupils from an educational perspective, and then they focus on specific subject areas and pupils' learning processes. Finally, pre-service teachers take holistic responsibility in their teaching and schools. (Niemi \& Jakku-Sihvonen, 2011) In the field of modern Teacher Education, the idea is to support the teacher's own professionalism. Teaching practice for future teachers follows an experimental approach, in which teachers research their own work. Teaching sessions which follow the experimental approach provide a way for the students to form their own educational philosophy based on theory and practice.

\section{Background of the Adult Class Teacher Education in Kokkola University Consortium}

Kokkola University Consortium Chydenius, in co-operation with the Faculty of Education at the University of Jyväskylä, arranges continuation courses leading to the degree of Master of Education and qualification as a primary school teacher. The Department of Education in Kokkola is the only permanent department in Finland which offers adult education for primary school class teachers. The educational program became permanent in 1994, which was a significant acknowledgement from the University of Jyväskylä towards the development work done at the Kokkola University Consortium Chydenius (Valli \& Meriläinen, 2008). The students come from a large area, nowadays increasingly from Western and Southern Finland. The education started as additional training in 1988, when its principal task was to reduce the national shortage of teachers. In addition to this, developing the teacher 
education curriculum and adult pedagogy became a central challenge. The annual intake of adult students for training as primary school teachers is 40 persons. All the students are required to have prior university studies and teaching experience. That is why the average age of the students is about 30-35 years. The studies last for 2 to 2.5 years, depending on the agreed individual study plan.

\section{My Own Class Practicum}

The class teacher education curriculum in Kokkola University Consortium Chydenius is built to support pre-service teachers' growth towards a deep teachership in the modern world. The learning process needs more collaboration; more project-based learning, more thinking, more analyzing, creativity etc. Teachers' work and the development of the teaching profession must be supported already during the studies so that one has ability and understanding to utilize different learning environments and modern tools easily and naturally in teaching and learning. Understanding how $21^{\text {st }}$ century skills connect to this is a central part of teachers' professional development, as Meriläinen and Piispanen (2012) argue in their report.

The final student teaching period in the Kokkola teacher education model is called My Own Class practicum (8 ECTS). According to Valli and Meriläinen (2006), this practicum is unique in Finnish teacher education, because in other teacher education programs student teaching is mainly organized in special training schools, owned by universities. In our teacher education program this practicum is organized in ordinary schools. My Own Class practice period can be seen as a training session which really resembles the work pre-service teachers will do as qualified teachers in their own classrooms after finishing their studies. The support they will get during the practicum is directed to those questions and issues that teachers meet in their daily work during the school year. Using modern information technology in making the training possible for all participants as well as making support easy to reach, we can offer our students a unique student teaching period in a very natural environment; an ordinary Finnish school with its daily routines.

My Own Class Practicum begins with contact teaching where pre-service students and their tutors together with the university teachers get to know the aims and contents of the forthcoming practice period. The tutors, who are qualified class teachers and will be working side by side with the pre-service teachers, are trained for their mission to help teacher students to grow in their profession during the practice period (Valli \& Meriläinen, 2006). When the practice period begins, the pre-service teachers have already moved back to their home areas, where they have at least a one-term-long contract with a local school. Their tutors, the tutor teachers, work at the same school as our preservice teachers, so distances between the university consortium and their working places can vary a lot.

During My Own Class Practicum, the students first draw a whole-term plan with integrated wholes that comprise the subject matter of the curriculum. 
From that basis, they make more explicit and detailed short term-plans for three weeks at a time. These plans also include goals for $21^{\text {st }}$ century skills. In addition, the student teachers plan one school day when a university teacher can view their work in the classroom in real time. Students are guided beforehand in the planning work, and they get feedback from their plans. After the three-week student teaching period each student writes a synthesis, reflecting what he has learned and his own theory-in-use. This synthesis and the entire process is the basis for the final discussion with the tutor.

\section{Research Tasks and Data}

In Finland, teachers are allowed to choose the teaching methods they use, and so they also have freedom to choose where and when they implement $21^{\text {st }}$ century skills. Therefore it is extremely important that graduating teachers have such professional abilities as to implement $21^{\text {st }} \mathrm{CS}$ in their work skillfully and with courage. Norrena, Kankaanranta and Nieminen (2011) refer in their article to Dali (1998), who writes that schools should prepare pupils to work as members of the future society. This can be understood as applying to teacher education as well, since teachers must be able to guide pupils towards skills needed in future society, at the moment $21^{\text {st }}$ century skills.

In our research project we want to define how teacher students' skills and knowledge as regards $21^{\text {st }} \mathrm{CS}$ transfer into practice when students start working as class teacher right after graduation. In this study we will explore graduating class teachers' work during the final student teaching period (My Own Class practicum) from the perspective of $21^{\text {st }} \mathrm{CS}$, especially the following skills: critical thinking and problem solving, collaboration, creativity, and the use of technology. The research task is to define how these $21^{\text {st }}$ century skills display in the work of the student teachers $(n=21)$, more precisely in their learning whole plans and in their work during My Own Class practicum.

The research data was collected in September and October 2013 from student teachers participating in My Own Class practicum. The data consists of students' teaching plans, videotaped lessons, and students' reflective syntheses of their practice period. The video material $(n=6)$ used as data in this study was chosen among all videotaped material $(n=21)$ for reasons that they had taken into account all four above mentioned $21^{\text {st }}$ century skills in the planning phase. The video material was used in defining how $21^{\text {st }} \mathrm{CS}$ were implemented. The reflective syntheses were used to explore the significance of $21^{\text {st }} \mathrm{CS}$ as part of pupils' learning for the student teachers.

\section{Reseach Methods and Analysis}

The data was analyzed using qualitative content analysis. According to Chi (1997), content analysis is applied to study mainly verbal material. In content analysis, the researcher aims to analyze contents and structure related to the 
studied phenomenon by making classifications or categorizations. Thereby, content analysis aims at producing information and understanding of the phenomenon in question (Downe-Wamboldt, 1992). In this study qualitative content analysis is the process where students' teaching plans, videotaped lessons, and written syntheses are thematically classified and subjectively interpreted. We have aimed at identifying some $21^{\text {st }} \mathrm{CS}$ and their significance in student teaching in the data. The $21^{\text {st }}$ CS that were chosen as the focus of this study, namely thinking skills, working skills, and tool skills, form the framework for classification. Critical thinking and problem solving, collaboration, creativity, and technology skills were chosen as sub-categories of the above mentioned broader categories. The display of these skills in planning teaching as well as their incorporation in the classroom was explored in this study. In this article, content analysis is seen as the identification and categorization process of $21^{\text {st }}$ century skills, and as the subjective interpretations made on the basis of the results.

\section{Research Results}

The results were taken under scrutiny firstly from the point of view of planning. Students' whole-term plans clearly displayed emphasis on collaboration. Every student had described collaboration as the basis of teaching. Another skill that the students clearly wanted and aimed to improve was critical thinking and problem solving skills. This was apparent already in the first phase of planning, and the students described it as follows:

"My teaching aims at making pupils active in learning. Teaching is based on the earlier thinking structures of the pupil, which makes learning a goal-oriented process, often including problem solving. As a teacher I guide their learning and we will practice together, and thus pupils get from each other inspiration that improves their thinking and imagination." (Pre-service teacher 20)

"The children practice working in pairs and different groups and problem solving." (Pre-service teacher 8 )

"As a teacher, I can try to support the development of a pupil's own understanding. When a pupil gets a possibility to think and discover things himself, that will certainly improve his understanding. Learning through practice supports the application of information and knowledge in novel situations. " (Pre-service teacher 12)

In their short-term plans, students set goals also for $21^{\text {st }}$ century skills. It was possible to detect different categories among the goals, such as collaborative skills, thinking skills and ICT literacy. Collaboration and ICT literacy were mentioned in all plans, but thinking skills (critical thinking and problem solving) only in six plans. The term creativity was mentioned in only 
one of all plans, but pupils' own thinking and creative processes had been taken into account in a couple of plans that mentioned the words imagination and own ideas. It was interesting that those students that had mentioned problem solving and critical thinking, had also taken creativity into account. Thus, students could be roughly divided into two categories according to their plans: students who take into consideration only collaboration and ICT literacy and students who take into account all four $21^{\text {st }} \mathrm{CS}$ (see Figure 1).

As mentioned, students were to plan a whole school day that the university teacher could follow in real time. These lessons were also saved for later scrutiny. Every student's school day included collaboration. Pupils worked in pairs and groups doing different tasks. ICT skills were also used during all students' school day. We chose six students, whose plans comprised all four $21^{\text {st }}$ century skills, under closer scrutiny. Their saved school days and practicum syntheses formed the basis for a more detailed definition of a teacher who mastered $21^{\text {st }} \mathrm{CS}$ well in the practicum.

Figure 1. Taking into Account $21^{\text {st }}$ CS from Students' Point Of View

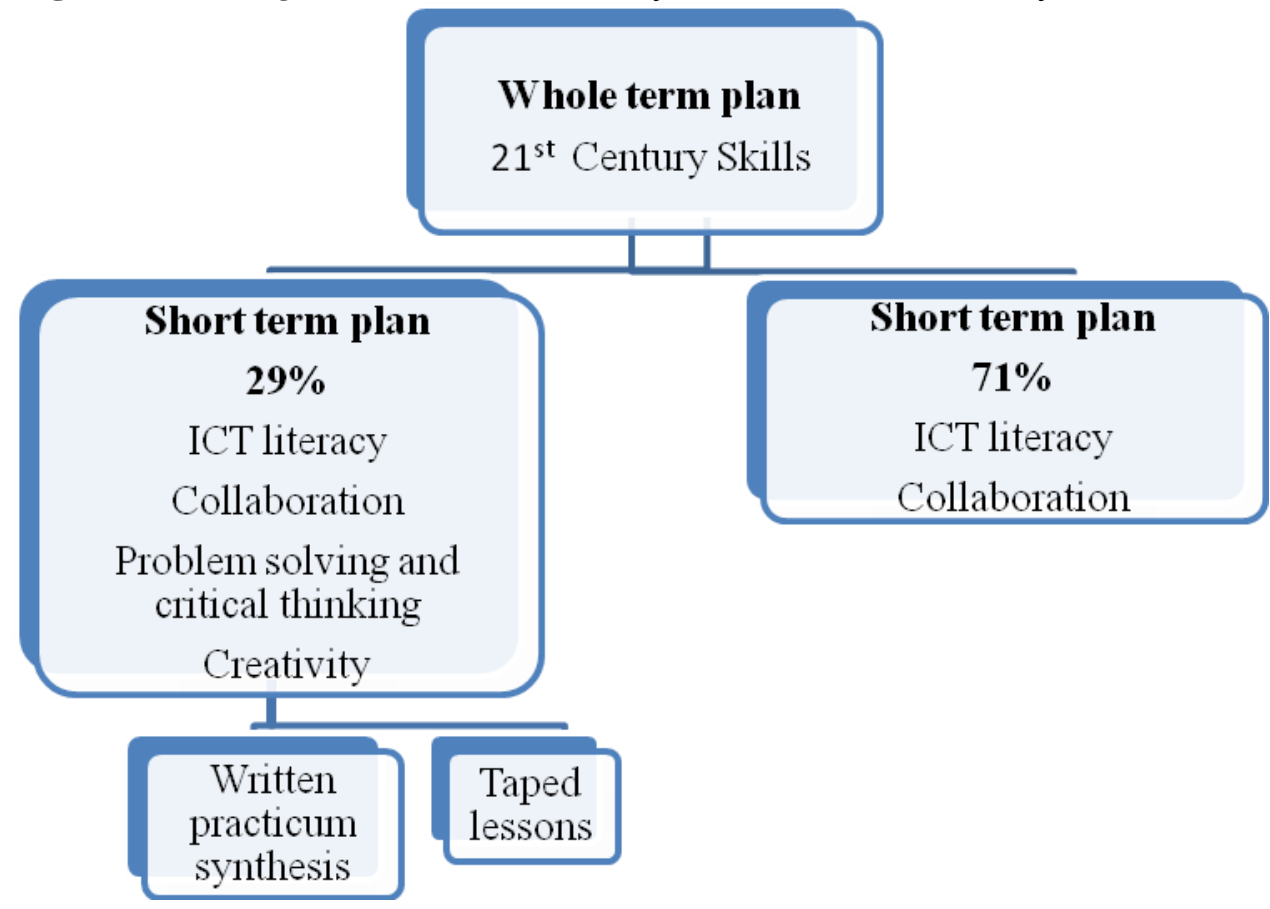

Next, we will briefly describe the school days implemented by six students, especially from the point of view of $21^{\text {st }}$ century skills. The phenomena the students had chosen for the school day were related to travel agencies and outdoor guides, among others. Methods were mostly such that activated and involved the pupils. Creativity was shown, for example, in the soundscape that the pupils created with instruments according to their observations in the nature, or in pupils' possibility to compose logos by themselves. The students commented this in the following way:

"Even during their break I heard pupils discuss about ideas on how to make a travel guide. During the first day the pupils created ever 
so fine and creative logos for their travel agencies." (Pre-service teacher 7)

"It is important that pupils can express themselves in versatile ways and to experiment and practice with mew tools." (Pre-service teacher 2)

Problem solving occurred in, for example, situations where the pupils studied nature-related things in pairs in a problem-based way. Creativity and problem solving occurred best when there was not just one right answer for the problem, and the problems were related to the world outside school. ICT skills were used in multiple ways, taking into consideration the skills level of the pupils. First grade pupils took photos on their outdoor excursion and in pairs chose a photo that they wanted to include in the class' common outdoor guide. They were also to critically assess the photos and give reasons for their choice. A student told us he had closely thought about questions he should ask the pupils in order to improve their thinking. One student's pupils kept a diary with the computer in pairs during the entire practice period. The diary entries were expanded with theory gained from different sources. In generally, ICT skills were used in a very versatile way in the classrooms of the six students.

The students had described $21^{\text {st }}$ century skills in their practicum syntheses and reflected what they had learned. The students were of the opinion that education had made them aware of $21^{\text {st }} \mathrm{CS}$ and provided them with a lot of good information. They also thought that earlier student teaching periods had given them $21^{\text {st }} \mathrm{CS}$ related experience. Pre-service teacher number 15 wrote:

"Education has provided me with $21^{\text {st }}$ century skills as a part of my work. I was of the opinion they are impossible to implement with small pupils, but I have had to discard this belief following this practicum."

The syntheses of the students showed that they considered themselves to be beginners in using $21^{\text {st }}$ century skills in their teaching. The following statement illustrates this:

"Including $21^{\text {st }}$ century skills in teaching is on experimental and practice level. I am making pupils aware of these skills little by little, and we will practice them for the future." (Pre-service teacher 4)

Students were also enthusiastic about using ICT in teaching, and they felt confident with using ICT. The students had included technology permanently into teaching and considered it as an important part of learning. Like Hooper and Rieber (1995) say that the adoption of technology happens in phases, it can be said that the students have understood the pedagogical possibilities of technology, when the teacher redefines his teaching and the purpose of the 
classroom, and with technology creates learning environments that support learning.

The students were of the opinion that collaboration has several positive effects on teaching and nearly all students emphasized the fact that it improves pupils' motivation and responsibility. Students' syntheses showed that they have found new perspectives into their work as teachers, which supports taking into account $21^{\text {st }}$ century skills in the classroom. Pre-service teacher number 16 wrote in his synthesis:

"Now, being a teacher is more guiding pupils to become critical knowledge builders who can work in cooperation with different people and have courage and abilities to express themselves."

\section{Conclusions and Implications}

Our results are in line with latest $21^{\text {st }}$ century skills studies (Norrena, 2013; Adamson \& Darling-Hammond, 2010; Partnership for $21^{\text {st }}$ Century Skills, 2011). Jyrhämä (2002) states that a student may have acquired a lot of theoretical knowledge which has become a part of his theory-in-use, but applying it all in teaching situations may be challenging. Students' different backgrounds and teaching experiences may affect their ability to apply the knowledge, which also partly explains this study's results about the students' abilities to implement $21^{\text {st }} \mathrm{CS}$ in practice. For some students adopting $21^{\text {st }} \mathrm{CS}$ is easier than for others. Some students have gained more experience in $21^{\text {st }} \mathrm{CS}$ during earlier student teaching periods, and therefore it was easier to take into account and apply the skills during My Own Class practicum. All students had experience in working as a teacher. Due to this one explaining factor of the results concerning $21^{\text {st }} \mathrm{CS}$ might be the confidence and understanding that work experience brings. There are differences between experienced and beginning teachers, which manifest itself in their ability to reflect on their work. Beginning teachers typically pay more attention to the subject than to the needs of pupils (Kansanen, 2004).

We noticed that the guidance students received had a great influence on how $21^{\text {st }} \mathrm{CS}$ were taken into account. It often happens that a student writes down $21^{\text {st }} \mathrm{CS}$ as learning objectives in plans, but they remain just concepts. A tutor's task is to ask the student to form more concrete goals of the concepts, and to explain what activity makes the students achieve and also do these goals. Transferring $21^{\text {st }}$ century skills into visible pedagogical activity demands the students not only awareness of the skills, but also of studentteachers'pedagogical thinking, and the ability to bridge theory and practice. According to Kansanen (2004), thinking is pedagogical when it relates to the aims and goals of the curriculum. Pedagogical thinking is also the ability to give reasons for one's solutions with the help of theory. It is about the teacher's pedagogical beliefs, practical knowledge and theory-in-use behind it. Thus, it is a question of two things: the students' own learning process and his ability to 
guide pupils to practice and also apply $21^{\text {st }}$ CS (compare Rotherham\& Willingham, 2010).

In addition, $21^{\text {st }} \mathrm{CS}$ must be taken into account in the evaluation of the pupils' needs analysis already at the planning stage. Adamson and DarlingHammond (2010) refer to Ahonen, who says that the teaching and evaluation methods of $21^{\text {st }} \mathrm{CS}$ are still forming in Finnish schools. Everyone agrees that these skills must be taught and used, but teachers are still asking for research on what methods they should use. The knowledge and skills gained during teacher education can be seen as models for how students become aware of and implement $21^{\text {st }} \mathrm{CS}$ as future teachers. The starting point of our training is community, and for this reason the students work in permanent teams (three students in one team) during their education, showing their competence through learning tasks instead of exams. We are of the opinion that the pedagogic thinking of our education works as a model for the students: we are teacher educators, therefore our activity must be in line with the goals of our curriculum. $21^{\text {st }} \mathrm{CS}$ should be visible in all learning in teacher training, and it is important to explain this way of thinking to the students, so that they can better understand the connection between theory and practice.

We think implementing $21^{\text {st }} \mathrm{CS}$ in schools is possible, but it requires certain factors that have to be taken into account. Firstly, the curriculum must include $21^{\text {st }} \mathrm{CS}$ and they must be represented in all subjects, cross-disciplinary, at skills' level (compare Norrena, 2013; Vitikka, 2009). Secondly, teacher training must provide the necessary knowledge and skills to use $21^{\text {st }} \mathrm{CS}$. It is a question of the teacher's pedagogic thinking and views of learning. Teacher training and continued education can support more learner -centered teaching and more versatile methods. Thirdly, assessment must be transparent and include assessment of $21^{\text {st }} \mathrm{CS}$ in addition to subject matter. The renewal process of the Finnish national core curriculum is one of the means to improve the situation in Finland. Teacher training faculties have a central role in developing the acquisition of $21^{\text {st }}$ century skills.

\section{References}

Adamson, F. \& Darling-Hammond, L. 2010. Policy Pathways for $21^{\text {st }}$ Century Skills. http://atc21s.org/wp-content/uploads/2013/02/ATC21S_Policy_Paper-20120730. pdf

Ananiadou, K., \& Claro, M. 2009. $21^{\text {st }}$ century skills and competences for New Millennium Learners in OECD countries. Paris, France: Centre for Educational Research and Innovation (CERI) - New Millennium Learners.

Berelson, B. 1952. Content Analysis in Communication Research. New York: Free Press.

Chi, M. 1997. Quantifying qualitative analyses of verbal data: A practical guide. The Journal of the Learning Sciences, 6, 3 (Publ. online Nov 2009), 271-313. DOI= http://doi.acm.org/10.1207/s15327809jis0603_1

Dewey, J. 1929. The quest for certainty. A study of relation of knowledge and action. London: Milton Balch. 
Downe-Wamboldt, B. 1992. Content analysis: Method, applications, and issues. Health Care for Women International, 13, 3, (Publ. online Aug 2009) 313-321. DOI=http://doi.acm.org/10.1080/07399339209516006

Gordon, J., Halasz, G., Krawczyk, M., Leney, T., Michel, A., Pepper, D., Putkiewicz, E. \& Wisniewski, J. 2009. Key competences in Europe: Opening doors for lifelong learners across the school curriculum

and teacher education. Warsaw: Case-Center for Social and Economic Research.

Hakkarainen, K., Bollström- Huttunen, M., Pyysalo, R. \& Lonka, K. 2005. Tutkiva oppiminen käytännössä. Matkaopas opettajille. [Progressive inquiry in practice. A travel guide for teachers.] Helsinki: WSOY.

Hooper, S. \& Rieber, L. 1995. Teaching with technology. In A. C. Ornstein, (Ed.) Teaching: Theory into practice. Boston: Allyn and Bacon, 154-170.

Häkkinen, P. Juntunen, M. \& Laakkonen, I. 2012. Tulevaisuuden oppimisympäristöt? Yksilölliset ja yhteisölliset oppimisen tilat. [Future learning environments? Shared and personal learning spaces.] In K. Pohjola (Ed.) Uusi koulu. Oppiminen mediakulttuurin aikakaudella. [New School. Learning in the era of media culture.] University of Jyväskylä. Finnish Institute for Educational Research, 5164.

Jyrhämä, R.(2002. Ohjaus pedagogisena päätöksentekona. [Supervision as pedagogical decision-making.] Department of Teacher Education. Research Report 236. University of Helsinki.

Kansanen, P. 2004. Opetuksen käsitemaailma. [Concepts of teaching.] Jyväskylä: PSkustannus.

Kuuskorpi, M. 2012. Future physical learning environment. User oriented flexible and changeable teaching spaces. University of Turku. Faculty of Education. Department of Teacher Education in Rauma.

Lankinen, T. 2010. Preface. In K. Vähähyyppä (Ed.) Koulu 3.0. [School 3.0.] Helsinki: Finnish National Board of Education, 4-5.

Ministry of Education and Culture 2014. Finnish student performance in PISA 2012 problem-solving assessment one of the best. Press release. http://www.minedu. fi/OPM/Tiedotteet/2014/04/Pisa_ongelmanratkaisu.html?lang=fi\&extra_locale=e $\mathrm{n}$

Meriläinen, M. \& Piispanen, M. 2012. Learning as a phenomenon-manuscript of phenomenon based learning. $4^{\text {th }}$ International Conference on Education and New Learning Technologies. Barcelona, Spain, 5447-5454.

Niemi, H. \& Jakku-Sihvonen, R. 2011. Teacher education in Finland. In M. Valenčič \& J. Vogrinc (eds.) European Dimensions of Teacher Education - Similarities and Differences. Faculty of Education, University of Ljubljana, Slovenia and The National School of Leadership in Education, Kranj, Slovenia, 33-52.

Norrena, J. 2013. Teacher Enhancing 21st Century Skills: "If You Want To Teach Those Skills You Must Master Them Yourself." University of Jyväskylä. Jyväskylä Studies in Computing 169.

Norrena, J., Kankaanranta, M. \& Nieminen, M. 2011. Kohti innovatiivisia opetuskäytänteitä. [Towards innovative teaching methods.] In M. Kankaanranta (Ed.) Opetusteknologia koulun arjessa. Jyväskylän yliopisto. Koulutuksen tutkimuslaitos, 77-100.

Partnership for 21 st Century Skills 2011. Project web page. Available at www.p21.org 21st Century Knowledge and Skills in Educator Preparation. http://www.p21. org/storage/documents/aacte_p21_whitepaper2010.pdf

Rotherham A.J. \& Willingham D. 2010. $21^{\text {st }}$ Century Skills: The Challenges Ahead. Educational Leadership 67,1 (Aug 2010),16-21. http://www.ascd.org/publicatio 
ns/educational-leadership/summer10/vol67/num10/21st-Century-Skills@-The-

Challenges-Ahead.aspx

Ryle, G. 1949. The Concept of Mind. London: Hutchinson.

Sahlberg, P. 2007. Education policies for raising student learning: the Finnish approach. Journal of Education Policy 22, 2 (March 2007), 147-171. DOI=http:// doi.acm.org/10.1080/02680930601158919

Valli, R. \& Meriläinen, M. 2006. Class Teacher Education and Training in Natural Environment. In C.M. Crawford (Ed.) International Conference Annual. March 20-24. Orlando, Florida, USA, 4307-4312.

Valli, R. \& Meriläinen, M. 2008. Modern information technology: a possibility to create a unique practicum period. E-Learn 2008. World Conference on ELearning in Corporate, Government, Healthcare, \& Higher Education. Association for the Advancement of Computing in Education. Las Vegas. USA, 1843-1850.

Vitikka, E. 2009. Opetussuunnitelman mallin jäsennys: Sisältö ja pedagogiikka kokonaisuuden rakentajina. [Structuring curriculum design: content and pedagogy constructing the whole.] University of Helsinki: Research in Educational Sciences 44.

Välijärvi, J. 2005. Muutoksen kohtaaminen opettajan työssä. [Facing change in teacher's work.] In O. Luukkainen \& R. Valli (Eds.) Kaksitoista teesiä opettajalle. [Twelve theses for a teacher.] Jyväskylä: PS-kustannus, 105-120. 
